\title{
Physical, functional and amylograph pasting properties of cocoyam-soybean-crayfish flour blends
}

\author{
Oti, E. ${ }^{1}$ and Akobundu, E. N. T . \\ ${ }^{1}$ Postharvest Technology Programme, National Root Crops Research Institute, \\ PMB 7006, Umuahia, Nigeria and ${ }^{2}$, Department of Food Science and Technology, \\ Michael Okpara University of Agriculture, Umudike, Umuahia, Nigeria \\ * Address for Correspondence Email : eooti@yahoo.com
}

ABSTRACT

\begin{abstract}
Four composite flours prepared by combining cooked cocoyam cormels, cooked soybeans, and dried crayfish in the ratios 80:15:5. 70:25:5, 60:35:5. 50:45:5 were analyzed for selected physical and functional properties. The composite flours were reconstituted into pastes and the relative viscosities of the pastes determined. The amylograph pasting viscosities of the blends were also measured. Wettability and bulk density (loose and packed) increased with increase in ratio of cocoyam flour in the mixture. The composite flours were not significantly different in water absorption capacity, their emulsion stabilities were low, and they formed very little and very unstable foams. The composite flour with the lowest ratio of cocoyam has a least gelation concentration of $18 \%$ (w/ v) flour, whereas the other three had a least gelation
\end{abstract}

concentration of $16 \%(\mathrm{w} / \mathrm{v})$ flour. There was a very strong tendency for the relative viscosities of the composite flours to increase significantly with increase in the proportion of the cocoyam flour in the mixture. Amylograph pasting viscosity measurements of the cocoyam-soybean-crayfish composite flours gave maximum (peak) viscosity values ranging from 4 to 75 Branbender units. As the proportion of cocoyam in the mixture increased the peak viscosity increased, whereas an increase in soybean ratio decreased the peak viscosity but increased the gelation temperature. The setback value of each composite flour was zero.

Key Words: Cocoyam-soybean-crayfish flour blends, physical, functional, amylograph pasting properties,

\section{INTRODUCTION}

$\mathrm{C}$ ocoyam (Colocasia and Xanthosoma spp.) $\mathcal{C}_{\text {is }}$ an under-exploited tuber crop although the literature is replete with its potential nutritional applications (Pedrama, 1978; Onwueme, 1987; Eleje, 1987; Idowu et al., 1996). The main nutrient in cormels of cocoyam is carbohydrate (mostly starch), Colocasia containing 13\% and Xanthosoma $17-26 \%$ carbohydrates on a fresh weight basis (Coursey, 1968). The size of cocoyam starch granule ranges from 3 - 20 micrometers, the extremely small size of Colocasia starch granule rendering it very easily digestible (Onwueme, 1987) thus making cocoyam suitable for complementary food production.
Approximately $35-40 \%$ of the total dry matter of soybean (Glycine max) is protein and about $20 \%$ contains highly polyunsaturated fatty acids (Emovon, 1987; Weingarner, 1987). Soybean lacks starch (Fukushima, 1991). Heating soybean denatures its proteins and the functional properties such as gelation, emulsification, foaming, and hydration are reflections of the protein structure of the denatured state (Yamauchi et al., 1991). Crayfish is a crustacean of the order Decapoda and contains $47.7 \%$ of protein on dry weight basis (Oti, 2003).

A number of food processing operations depend heavily upon rheological properties (deformation and flow characteristics) at an 
intermediate stage of manufacture because this has profound effect upon the quality of the finished product and hence its acceptability (Bourne, 1982). Starch gelatinization results from disruption or disorganization of the granule structure by heat and this event effects digestibility and texture of starch containing foods; leaching of amylase enhances susceptibility of starch to enzyme attack (Rickard, 1991) and the textural quality of utmost importance in certain foods is viscosity (Osman, 1967).

The objective of this study was to determine the pasting viscosity characteristics, and selected physical and functional properties, of mixtures of flours of cooked cocoyam cormels, cooked soybeans, and dried crayfish with a view to determining the suitability of the blends for complementary food production.

\section{MATERIALS AND METHODS Preparation of cocoyam soybean-crayfish flour blends}

A mechanical slicer (Multi Wonder UK Design No. S-309) was used to produce approximately $4 \mathrm{~mm}$ thick slices from peeled and washed cormels of cocoyam (Colocasia esculenta, var cocoindia). Three kilograms of the slices were boiled in 15 litres of potable water contained in aluminium pot for $15 \mathrm{~min}$. The cooked slices were oven-dried at $80^{\circ} \mathrm{C}$ for $9 \mathrm{~h}$., milled with a Premier Grinding Mill model 1A to obtain flour which was subsequently sieved through $0.35 \mathrm{~mm}$ sieve to yield a flour of fine texture.

Essentially the method of Faryana (1985) was used for processing the soybeans into flour. The soybeans were boiled in water (water:soybean $\mathrm{v} / \mathrm{v}$ ) was 2:1) in aluminium pot for $30 \mathrm{~min}$. After boiling, the soybeans were soaked in water $(2: 1)$ for $12 \mathrm{~h}$, and the water changed every $6 \mathrm{~h}$, The seed coats were removed by rubbing between the palms. The kernels were rinsed and dried in a forced air Gallenkamp oven at $80^{\circ} \mathrm{C}$ for $6 \mathrm{~h}$, the dried soybeans were milled with Premier Grinding Mill model 1A and the resulting flour sieved through $0.35 \mathrm{~mm}$ sieve to yield flour of fine texture.

Extraneous materials were removed from the crayfish by hand picking and winnowing. The sorted crayfish was then washed, placed in meshed aluminium container for water to drain, dried in forced air Gallenkamp oven at $80 \mathrm{oC}$ for $4 \mathrm{~h}$, and milled with the dry mill of National Quickie-Mini blender into flour which was subsequently sieved with $0.35 \mathrm{~mm}$ sieve to produce flour of fine texture.

Composite flours were prepared from the cocoyam, soybean, and crayfish flours in the ratios 80:15:5, 70:25:5, and 50:34:5 and the samples were designated CSC 1, CSC 2, CSC 3 and CSC 4, respectively.

\section{Assessment of Physical Qualities of Cocoyam-} Soybean-Crayfish Composite Flour

Wettability and bulk density (loose and packed) of the cocoyam-soybean crayfish composite flours were determined by the method of Okezie and Bello (1988). Relative viscosity of the composite flour was estimated by the method of Asinobi et al. (1998). The estimation involved determining the time taken by a ball bearing weighing $2 \mathrm{~g}$ dropped in a paste of the composite flour to fall to the bottom of $100 \mathrm{ml}$. measuring cylinder containing the paste. The paste was prepared by reconstituting $20 \mathrm{~g}$ flour with $85 \mathrm{ml}$ distilled water. The relative viscosity was calculated using the following relation:

Relative viscosity $=\mathrm{h} / \mathrm{g} \times 100$, where $\mathrm{h}=\quad$ settling time of the ball bearing in the paste

$\mathrm{h}=\quad$ settling time of the ball in distilled water 


\section{Determination of the functional properties of the composite flours}

Functional properties (gelation property, water absorption capacity and foaming capacity/ foam stability) were estimated employing the method of Abbey and Ibeh (1988) and emulsion capacity/stability by the method of Okezie and Bello (1988) except that a micro-blender was not used. National Quickie-mini blender was used in place of a micro-blender and the weights of samples and volumes of oil-distilled water used were adjusted accordingly to maintain the weight to volume ratio.

\section{Determination of the Amylograph Pasting Properties of the Composite Flours}

The pasting characteristics of the cocoyamsoybean-crayfish composite flours were determined by the method of Rasper and Coursey (1967) using a Brabender amylograph. The standard mode was used in which the sample was heated at constant heating rate $\left(2.5^{\circ} \mathrm{C} / \mathrm{min}\right.$.) from starting point up to a final temperature $\left(95^{\circ} \mathrm{C}\right)$ and the viscosity was recorded at a constant rotational velocity (50 rev./min) of the measuring vessel.

\section{Statistical Analysis}

Analysis of variance was carried out on all data collected using Generalized Linear Model procedure of Statistical Analysis System (SAS) (1989).

\section{RESULTS AND DISCUSSION}

Bulk density (loose and packed) and wettability were highest in CSC 1 (flour with the highest cocoyam ratio) and lowest in CSC 4 (flour with the lowest cocoyam ratio) (Table 1). Significant differences $(\mathrm{p}<0.05)$ were observed among the composite flour samples with respect to these parameters.

Bulk density of foods increases with increase in starch content (Bhattachrya and Prakash, 1994). The packed and loose bulk densities of the composite flours tended to increase with increase in cocoyam flour content, and the cocoyam flour contained mainly starch (Coursey, 1968).

The composite flours were derived from cocoyam, soybean, and crayfish the proteins of which were denatured by heat processing, and denatured proteins bind more water (Padmashree et al., 1987). The time taken to dissolve the composite flours tended to decrease with increase in protein content of the flour thus suggesting that the higher the level of denatured protein in these flours the faster they imbibed water, or were wetted.

There was a very strong tendency for the relative viscosities of the composite flours to increase significantly with increase in the ratio of cocoyam flour in the mixture (Table 1). While soybean lacks starch (Fukushima, 1991), cocoyam contains mainly starch (Coursey, 1968). The cocoyam-soybean-crayfish composite flours contained gelatinized starch which formed viscous dispersions when the flours were reconstituted with water (Meyer, 1978). Consequently, composite flours which contained higher ratios of starch produced more viscous dispersions and correspondingly higher relative viscosities.

Significant differences $(\mathrm{p}<0.05)$ existed among the cocoyam-soybean-crayfish flours (CSC 1, CSC 2, CSC 3, CSC 4) with respect to emulsion capacity, but no significant differences ( $p>0.05$ ) were observed in water absorption capacity (Table 1).

Proteins aid in formation and stabilization of emulsion (McWatters and Cherry, 1981) and heat processing reduces emulsion capacity (Abbey and Ibeh, 1988). The emulsion capacities of the composite flours were low probably because the components of the composites were heat processed. CSC 3 and CSC 4 were higher in protein content than CSC 1 and CSC 2 (Table 2 ) and the former, in agreement with the findings 
of McWatters and Cherry (1981), were higher in emulsion capacity than the latter. The emulsion stabilities of the flour blends were also low (Fig. 1) apparently because none of the components of the blends is known to contain a substantial amount of any known natural stabilizer. In addition, the proteins which would have helped to stabilize the emulsions had been denatured by heat processing. The oil absorption capacities of the composite flours tended to increase with increase in protein content (Table 1) since the protein in foods influences fat absorption (Richest et al., 1974). The composite flours contained denatured proteins with high affinity for water (Padmashree, 1978) and no significant differthat cocoyam starch is not susceptible to retrogradation thus rendering it suitable for complementary food manufacture. Furthermore, the setback values of the cocoyam-soybeancrayfish composite flours were not different from that of NUTREND (a reference baby food) (Table 3).

\section{CONCLUSION}

The amylograph pasting characteristics of the composite flours (CSC 1, CSC 2, CSC 3, and CSC 4) clearly show that pastes produced from the composite flours containing $80 \%$ and $70 \%$ cocoyam flour (CSC 1 and CSC 2, respectively) were much bulkier (much more viscous) than the pastes from composites containing $60 \%$ and $50 \%$ cocoyam flour (CSC 3 and CSC 4, respectively). If a complementary food is bulky infants and young children cannot consume enough at a time to meet their energy needs. Diluting the food with water to make it less bulky may produce a paste with very low energy density which is not suitable for growing children. Appropriate quantities of food grade amylase may be incorporated into CSC 1 and CSC 2 to reduce their viscosity to acceptable degree when reconstituted without diminishing their energy density drastically. Alternatively, the soybean used in the production of the cocoyam-soybeancrayfish base foods could be malted to serve as a source of amylase.

Since the setback value of the composite flours was found to be zero, the starch of the composite flours (contributed solely by the cocoyam flour since both soybean and crayfish lack starch) is not susceptible to retrogradation (aggregation of part of starch to form microcrystals which precipitate). Pastes may be produced from the composite flours and stored without suffering retrogradation, thus obviating the difficulty encountered by infants and young children in digesting retrograded starch.

The following characteristics of CSC 3 and CSC 4 strongly commend them for use as base foods in complementary food production:

(i) They have a higher tendency than CSC 1 and CSC 2 to be wettable. This makes their reconstitution easier and faster.

(ii) They produce pastes of much lower viscosities than those of CSC 1 and CSC 2. This removes the need to incorporate amylase (a thinning enzyme) into the composites.

(iii) They have significantly higher protein contents than CSC 1 and CSC 2. High protein contents in complementary foods are desirable because of their functional. 


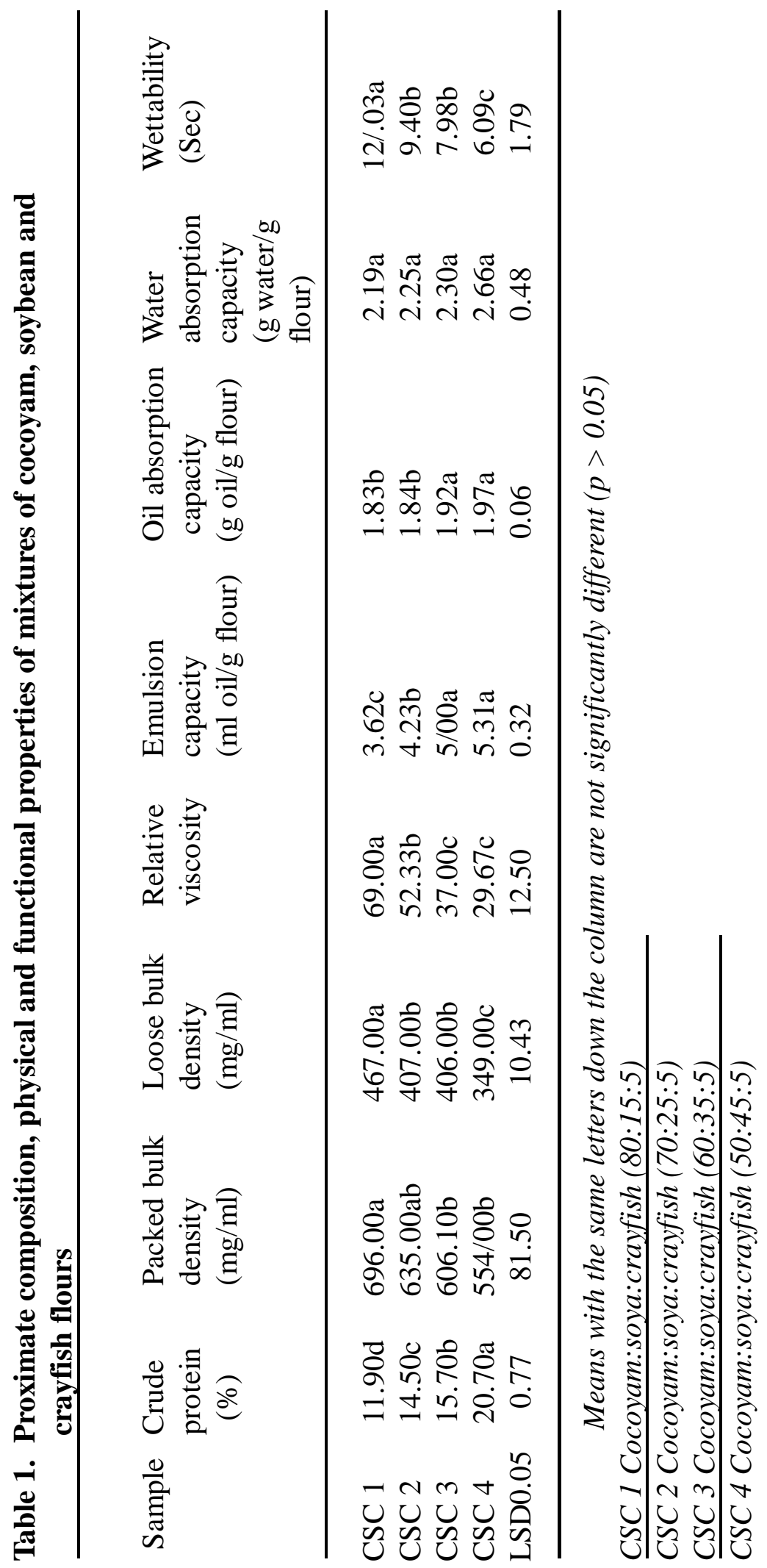




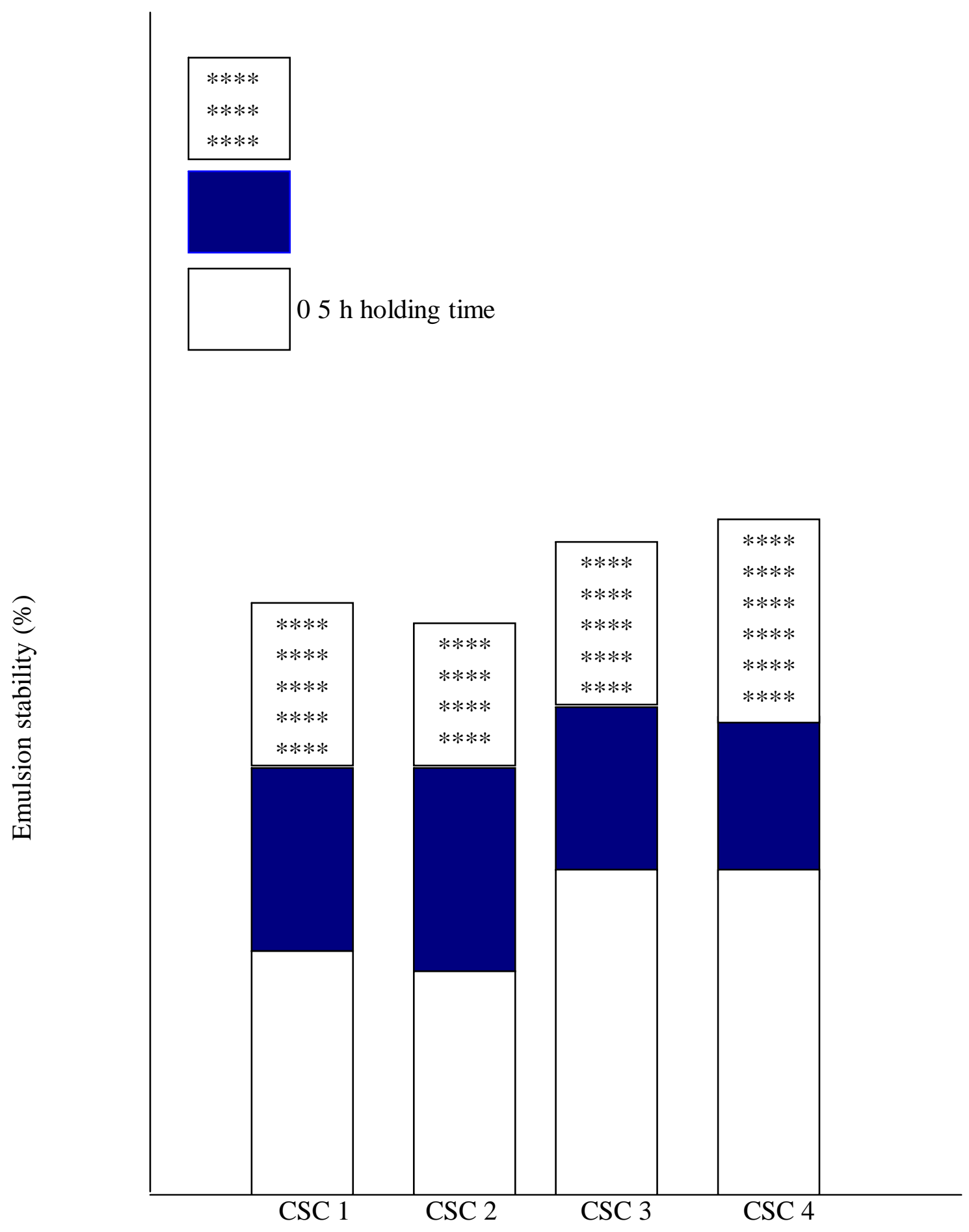

Cocoyam-soybean-crayfish Composite Flours

Fig. 1. Emulsion stability of cocoyam-soybean-crayfish composite flours CSC 1 (80:15:5 mixture), CSC 2 (70:25:5 mixture), CSC 3 (60:35:5 mixture), CSC 4 (50:45:5 mixture) 
Table 2. Least gelation concentration of mixtures of cocoyam, soybean, and crayfish flours

\begin{tabular}{ccccc}
\hline Concentration of mixture (\%) & CSC1 & CSC2 & CSC3 & CSC4 \\
\hline 2.0 & - & - & - & - \\
4.0 & - & - & - & - \\
6.0 & - & - & - & - \\
8.0 & - & - & - & - \\
10.0 & - & - & - & - \\
12.0 & - & - & - & - \\
14.0 & - & - & - & - \\
15.0 & G* & G & G & \\
18.0 & G & G & G & G \\
20.0 & G & G & G & G \\
\hline
\end{tabular}

* Gel formed

CSC 1 Cocoyam:soya:crayfish (80:15:5)

CSC 2 Cocoyam:soya:crayfish (70:25:5)

CSC 3 Cocoyam:soya:crayfish (60:35:5)

CSC 4 Cocoyam:soya:crayfish (50:45:5) 
Physical, Functional, and Amylograph Pasting Properties Of Cocoyam-Soybean-Crayfish Flour Oti Akobundu

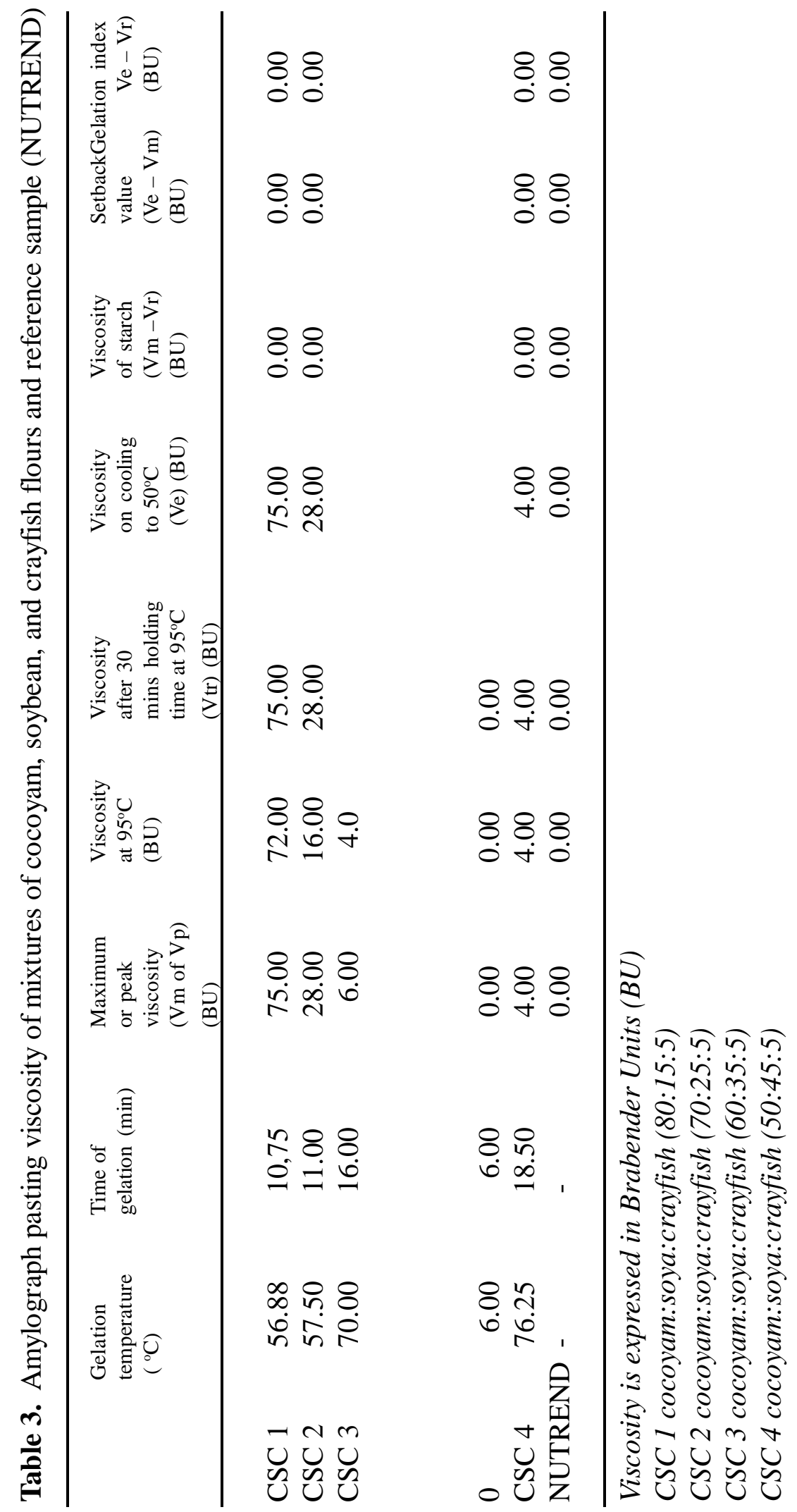




\section{REFERENCES}

Abbey, B. W. and Ibeh, S. O. (1988). Functional properties of raw and heat processed cowpea (Vigna unguiculata, walp) flour. J. Food Sci. 53(6); 1775 - 1791.

Asinobi, C., Ojimelukwe, P. C., Uzoe, M. C. and Onwuluzo, J. C. (1998). Comparative effects of various viscosity reducing treatments on the quality characteristics of cocoyam-sorghum infant food. J. Food Biochem. 22, $441-453$.

Bhattachrya, S. and Prakash, M. (1994). Extrusion blends of rice and chicken pea flours: A response surface analysis. J. Food Engr. 21; $315-330$.

Bourne, M. C. (1982). Food texture and viscosity concept and measurement. Academic press, New York, USA.

Coursey, D. G. (1968). The edible aroids. World crops $20,25-30$.

Eleje, I. (1987). Cocoyam: a major national carbohydrate staple food for the future in Nigeria. In: Arene, O. B., ene, L. S. O., Odurukwe, S. O., and Ezeh, A (ed).

N. O. A. (eds.) Proc. 1st National workshop on Cocoyams, p. 152 - 156. Aug. 16 - 21, 1987, NRCRI, Umudike, Nigeria.

Emovon, E. (1987). Keynote address at the Training workshop on Utilization of soya Bean in Nigeria. In: Proc. Of the Training workshop on soybean utilization, 9-14 March, 1987, Abu, Zaria Nigeria. Home Economics Series, No. 4, $6-10$.

Faryana, P. J. (1985). Soybeans in the Nigeria diet. Extension Bulletin No. 21, Home
Economics Series No. 1, AERLS, ABU, Zaria, Nigeria.

Fukushima, D. (1991). Recent progress in soybean protein foods: Chemistry, technology, and nutrition. Food Reviews International 7(3): $323-351$.

Idowu, M. A., Oni, A., and Amusa, B. M. (1996). Bread and biscuit making potentials of some Nigerian cocoyam cultivars. Nig. Food J. 14; 1 -11 .

Iwe, M. O. (1998). Effects of extrusion cooking on functional properties of mixtures of full-fat soy and sweet potato. Plant Foods Hum. Nutr. $53 ; 37-46$.

McWatters, K. H. and Cherry, J.P. (1981). Protein functionality in foods. In: Cherry, J. P. (eds.). Chem. Soc. Symp. Series No. 147, p. 217.

Meyer, L. H. (1978). Food Chemistry. The AVI Publishing Company Inc., Westport, Connecticut, xiv +385 p. 13 .

Ogazi, P. O. (1985). The rheological properties of plantain flour as composite with wheat flour. Nig. Food J 2; 190 - 193.

Okezie, B. O. and Bello, A. B. (1988). Physicochemical and functional properties of winged bean flours and isolate compared with soy isolate. J. Food Sci. 53 (2) ; 445 - 450.

Olatunji, O. and Akinrele, I. A. (1978). Comparative rheological properties and bread qualities of wheat flour diluted with tropical tuber and breadfruit flours. Cereal Chem. 55; 1 -6 . 
Onwueme, I. C. (1987). Strategies for increasing cocoyam (Colocasia and Xanthosoma spp) in Nigerian Food Basket. In: Arene, O. B., Ene, L. S. O., Odurikwe, S. O. and Ezeh, N. O. A. (eds.) Proc. 1st National Workshop on cocoyam, pp. 35 - 42, 16 - 21 Aug. 1987, NRCRI, Umudike, Nigeria.

Osman, E. M. (1967). Starch in Food industry. In: Whistler, R. L., and Paschall, E. F. (eds.). Starch: Chemistry and Technology, p. $163-215$. Academic Press, London and New York, USA.

Oti, E. (2003). Development and evaluation of cocoyam-soybean-crayfish based complementary food. PhD. Dissertation, Michael Okpara University of Agriculture, Umudike, Nigeria, Department of Food Science and Technology.

Padmashree, T. S, Vijayalakshim, L., and Puttaraj, S. (1987). Effect of traditional processing on functional properties of cowpea (Vigna catjjang) flour. J. Food Sci. Technol. 24; $221-225$.

Pedrama, C. (1978). Processing of root and tuber crop products especially Taro and Cassava in Western Samoa. In: Plucknett, D. L. (ed.). Small-scale Processing and Storage of Tropical Root Crops, p. 258 - 265. Western Press.

Rasper, V. and Coursey, D. G. (1967). Properties of starches of some West African yams. J. Sci. Food Agric. 18; 240 - 244.
Richest, S. H., Moor, C. V. and Coursey, C. M. (1974). The effect of heat and other factors upon foaming properties of whey protein concentrates. J. Food Sci. 39; 42.

Rickard, J. E. (1991). Quality aspect of tropical root crops starches. In: 9th Symp., Int. Soc. Trop. Root Crops, Ghana.

Sathe, S. K., Desphande, S. S. and Salunkhe, D.

K. (1982). Functional properties of winged bean Psophocarpus tetragonobulus (L) (DC) proteins. J. Food Sci. 47; 503.

Schoch, T. J. (1967). Properties and uses of starch. In: Whister, R. L. and Paschall, E. F. (eds.) Starch: Chemistry and Technology, p. $79-86$ Academic press, London and New York.

SAS (1989). Statistical Analysis System. User's Guide Version 6, Fourth Edition, Vol. 2. Carry, N. C.: SAS Inst., Inc., p846 .

Weingartner, K. (1987). Nutrition of soybean in Nigeria. In: Proc. Of the Training workshop on soybeans Utilization, p6-10, March $9-14$, ABU Zaria, Nigeria.

Yamauchi, F., Yamagishi, T., and Iwabuchi, S. (1991). Molocular understanding of heat-induced phenomena of soybean protein. Food Reviews International 7(3); $283-322$. 